\title{
Relationships Between Religious Beliefs and Mountain Pasture Uses: A Case Study in the High Atlas Mountains of Marrakech, Morocco
}

\author{
Pablo Dominguez • Francisco Zorondo-Rodríguez • \\ Victoria Reyes-García
}

(C) Springer Science+Business Media, LLC 2010

\begin{abstract}
This study explores the association between individual beliefs in local Islamic Saints in the High Atlas of Morocco and the use of the environment. This exploration is done within the framework of a traditional institution of natural resource management, based on the regulations (called Agdal) of access to common pastoral resources. Research methods included participant observation and interviews during several stays between 2003 and 2008 among the Amazig (Berber) people of the Mesioua tribe, and a survey of 80 households in the village of Warzazt. Our data show an association between the transformation of traditional individual beliefs in local Saints and new agro-pastoral practices that have previously
\end{abstract}

P. Dominguez $(\bowtie)$

Departament d'Antropologia Social i Cultural,

Universitat Autònoma de Barcelona,

08913 Bellaterra, Barcelona, Spain

e-mail: dominguezggpp@gmail.com

P. Dominguez

Laboratoire d'Anthropologie Sociale,

52 rue du Cardinal-Lemoine,

75005 Paris, France

P. Dominguez

Laboratoire Population-Environnement-Developpement,

3 Place Victor Hugo,

13331 Marseille, France

F. Zorondo-Rodríguez

Institut de Ciència i Tecnologia Ambientals,

Universitat Autònoma de Barcelona,

08193 Bellaterra, Barcelona, Spain

V. Reyes-García

ICREA and Institut de Ciència i Tecnologia Ambientals,

Universitat Autònoma de Barcelona,

08913 Bellaterra, Barcelona, Spain been linked to the disappearance of Agdal-managed pastures and biodiversity loss. We conclude that, in addition to the more material dimensions of climate change, population increase, migration, or expansion of cash economies, religious beliefs should also be taken into account when analyzing the use of natural resources and agro-pastoral change processes.

Keywords Religion · Ecology · Amazig/Berber · Morocco · Communal resource management $\cdot$ Agdal

\section{Introduction}

After many decades, researchers are still debating the effects on environmental conservation of natural resource uses based on communal property (the commons). Critics argue that unregulated use of the commons (i.e., open access) is very frequent, unsustainable, and far from a spirit of co-operation and fully democratic functions in a modern sense (Hardin 1968). However, advocates point out that as a counter-reaction many social, political, and religious institutions spring up locally, with the aim of establishing a socio-economically sustainable management of the commons, and a means of ecological conservation (Lansing 1987; Ostrom 1990; Elmqvist et al. 2004; Neves-Garca 2004; Cinner et al. 2006; Garcia et al. 2006; Parlee and Berkes 2006; Folke et al. 2007; Yafeng et al. 2009). Nevertheless, in either case, it is a fact that communal natural resource management institutions are frequently embedded in significant agricultural change processes (Turner and Brush 1987). Despite the large body of literature on the commons, researchers have paid scant attention to the role of individual religious beliefs in the processes of change in the management of territory and 
communal natural resources, although some have qualitatively suggested that the phenomena could be associated (Byers et al. 2001; Wadley and Colfer 2004).

In this paper we describe a traditional form of common property management, which is based on the regulations (called Agdal) of access to common pastures, mainly in spring, in order to obtain better grazing at the beginning of summer. This regulations is imposed by customary law and re-endorsed every year by the jmaa, a traditional tribal assembly and most fundamental institution of the local autonomous political system. The Ait Rbain, guardians chosen by the community of users, are in charge of the monitoring of this regulations and a system of graduated sanctions is imposed by the whole jmaa on different types of Agdal offenders. Nevertheless, rather than examining the potential role of the Agdal, we examine the underresearched relationship between individual beliefs in local Saints of the High Atlas of Morocco (closely linked to local religious tradition) and the use of Agdal managed pastures in a context of substantial agricultural change.

Changes in agriculture result from very diverse factors, such as changes in demography, climate, technology, politics, or economy. For example, changes in common property management institutions can appear to be affected by demographic growth (Hardin 1968; Fillat 2003). This, in developing countries, is often accompanied by the fragmentation of the commons for individual intensification of agricultural practices, creation and extension of farming lands, the increase of irrigation, etc. (Turner and Brush 1987; Herzenni 1993). Similarly, changing climatic conditions, such as the succession of dry years and scarcity of snow during recent decades in the High Atlas, can also negatively affect the performance of many commons and the functioning of indigenous management institutions (Bellaoui 1989; Alaoui-Haroni 2009; Auclair and Alifriqui 2010). Technological advances and contemporary socio-economic changes can also bring about decimation of common natural resources and result in significant social inequities that may also put the commons in crisis (Baland and Platteau 1999; Godoy et al. 2005; Lu 2007; Romagny et al. 2008; Thoms 2008). For example, Thoms (2008) shows how local Nepali elites, reinforced by socio-economic changes and external policies, dominate community forest user groups, and how such conditions of inequity severely challenge the maintenance of community-controlled natural resources. In fact, the combination of all these factors (changes in demography, climate, technology, politics, or economy) is very common and can easily intensify a variety of natural resource crises (Bourbouze 1999).

Several authors have found that, in addition to these factors, cultural or religious beliefs can also affect the management of communal natural resources (Byers et al. 2001; Kingsbury 2001; Wadley and Colfer 2004; Yafeng et al. 2009). Here we do not conceive religion as a social institution in its own right (Dianteill 2002) but concentrate on individual religious beliefs on the assumption that they can specifically influence processes of agro-pastoral change because they are autonomous within the general religious institutional structure.

In this article, we provide a quantitative test of the association between individual religious beliefs and natural resource management as highlighted qualitatively by previous research. For example, Byers et al. (2001) found that religious beliefs influence behavior towards woodlands among communities in Zimbabwe, where sacred forests are larger and more continuous than non-sacred forests. Wadley and Colfer (2004) found a similar relationship between sacred spaces and biodiversity conservation in Indonesia. These works suggest that, at least in some cases, religious beliefs may be of pivotal importance in addressing ecological conservation issues. Nevertheless, research on this subject is mostly qualitative and does not focus on either the process or the drivers of change. Here, we present a quantitative analysis of the association between individual religious beliefs in local Saints and the practice of the Agdal in the context of marked agricultural change and a transformation in the belief system. Since researchers have suggested that the Agdal practices contribute to ecological sustainability (Alaoui-Haroni 2009; Auclair and Alifriqui 2010; Dominguez and Hammi 2010), our results may help to highlight the importance of such an association in environmental terms.

We use the terms 'traditional' and 'religious' because these are the terms that local people use. The term 'traditional' refers to all that is conceived as having existed for one or more previous generations; 'religious' designates anything that refers to the immaterial world in the form of the message of God or metaphysical reflection. In this sense, the traditional beliefs in Saints are mainly taken as religious since, for many local believers, it means following the message of God.

\section{The Human and Geographical Setting}

We conducted fieldwork in the village of Warzazt, Morocco, situated at 2,000 meters above sea level with approximately 620 inhabitants belonging to the Mesioua tribe. Located in the basin of the Zat valley, as the crow flies Warzazt is less than $50 \mathrm{kms}$ from Marrakech (Fig. 1). It is, nonetheless, very difficult to access and only a sand trail, usable for just 2 months a year by $4 \times 4$ vehicles, links Warzazt with the outside world. The rest of the year access is by mule or on foot. Warzazt lies at the entrance of the Yagour, a 70 square $\mathrm{km}$ high mountain pastoral territory. The Yagour is communally owned and used by 7,500 people of around 50 villages. Warzazt is part of this group 
Fig. 1 Situation and limits of the Mesioua tribe and Warzazt in its interior

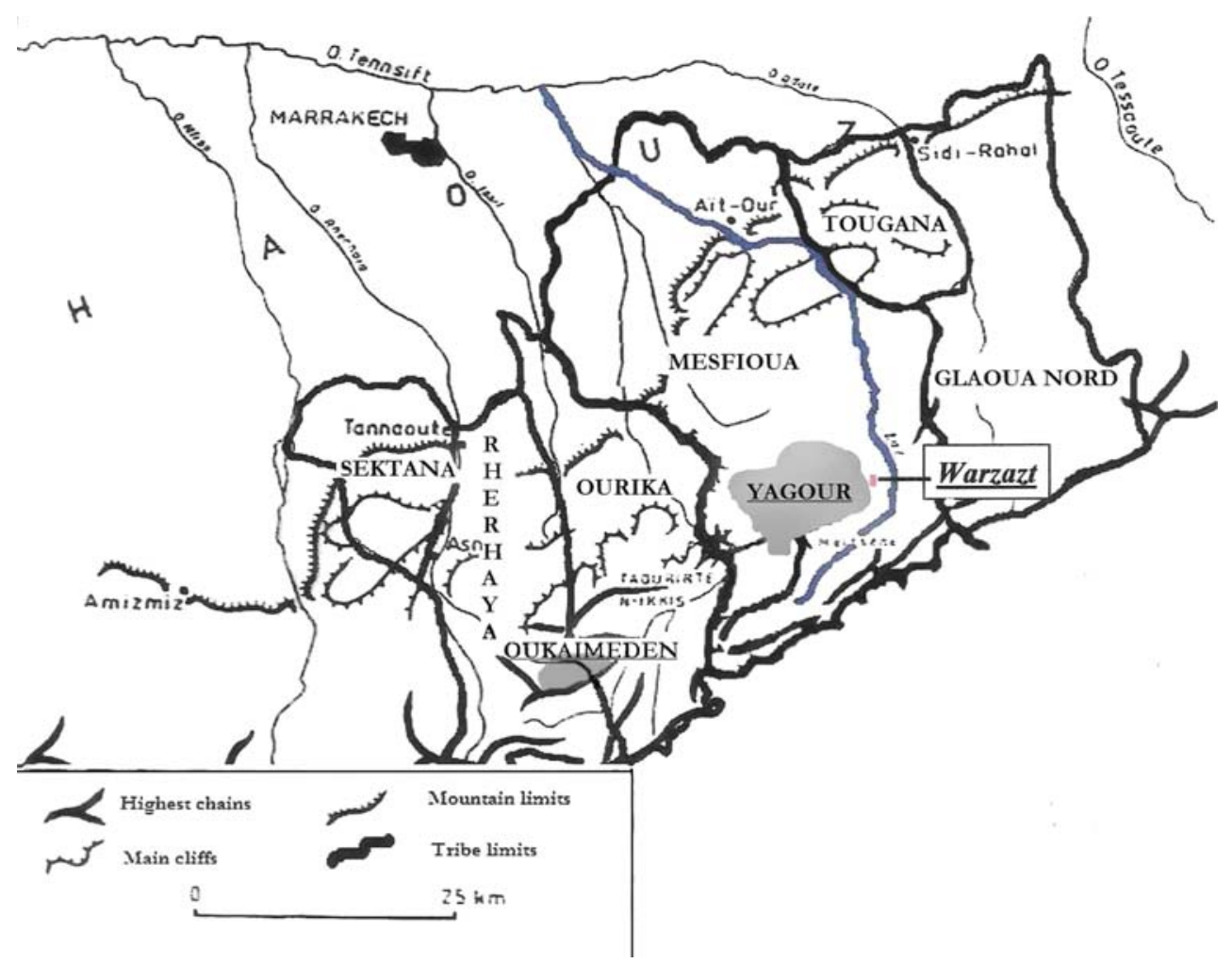

of villages and owns part of the Yagour (Yagour n'Ikiss). Herding in the Yagour is prohibited by the Agdal for approximately 3 months after the 28th of March. This allows the pasture to rest and replenish during its most vulnerable period of growth (Bourbouze and Quarro 2000).

Warzazt and the neighboring villages retain the segmentary structure of the traditional tribal organization (Gellner 1969; Evans-Pritchard 1970; Netting 1986). The Mesiouia are patriarchal and, as in other Berber societies, all the decisions about a household's use of agro-pastoral resources are made by the male head of household. In his absence, decisions are made by the eldest adult male of the family.

We cannot measure changes in beliefs in Saints through time and how these relate to ongoing changes in natural resource uses because we have not undertaken a diachronic study. Even so, Warzazt offers a very good case study of the relationship between individual beliefs in Saints and ecological management practices, because these elements have locally undergone substantial changes, as we explain below, permitting us to measure people's level of belief and natural resource use, thereby indicating at what stage of this process of change they find themselves.

\section{Traditional and Current Beliefs in Saints in the Agdal of Yagour}

Traditionally the prohibition period imposed by the Agdal was strongly legitimized and supported by long-held religious beliefs in the descendents of the main local Saint, Sidi Boujmaa, who are considered by locals as Saints themselves. These descendants form a community that constitutes a local morabitic institution (a centre for Islamic teaching and thinking that is frequently seen by the local populations as a mediator with God). Until the 1970s the lifting of the annual Agdal prohibition was announced by the descendants of Sidi Boujmaa in the weekly market on the first Friday (the Muslim day of prayer) after the start of Berber summer, the 28th of July, thus blessing the opening.

Then, about a week later, the people of Warzazt would honor Sidi Boujmaa through ritual offerings (i.e., grain, vegetables, butter, elaborate food, sacrifices of cattle, etc.) that were presented to the Saints' descendents, traditionally next to the grave of the patron. Tradition held that, in return, the buried saint would assure the prosperity and the fecundity of those who had honored him, and their animals, especially through the protection of their natural resources and the Agdal regulations. In fact, all our informants state that up to 50 years ago everybody practiced traditional Islam, and believed deeply in the Saints.

Nevertheless, our research indicates that belief in the Saints and their relationship with the Agdal regulations has decreased among a large part of the population. This decrease, which varies according to age, gender, socioeconomic status, etc., has voided the Agdal regulations of much of its mystical content (even if many still maintain their beliefs), and this may be associated with changes in more traditional pastoral practices. For example, many no 
longer believe that the annual deactivation of the Agdal has to be announced by the Saint's descendants in order to receive the blessing of God, and access to the Yagour now opens before its traditional date, sometimes up to a month and a half earlier, with the authority of the jmaa. Similarly, large areas of the grazing lands, once believed by everybody to be protected and preserved by the Saints, are now being used for intensive and widespread agriculture. Furthermore the patron Saint of the Agdal no longer receives the collective honor and favors from the village of Warzazt. Some even say that the Saints' descendants are simply robbers. The reasons for the diminution of traditional religiosity may be related to the arrival of obligatory state schooling, generational cultural change, the rise of a more orthodox Islam that is intolerant of veneration of the Saints, television, market economy and other agents of cultural globalization. As a result, society has diverged into a broad spectrum between believers and non-believers in traditional Saints.

\section{Traditional and Current Uses of the Yagour}

The Yagour has traditionally been a summer pasture subject to the Agdal herding restrictions. Over the last 40 years, uses of the Yagour have undergone two main changes. First, in the 1960s, with systematic zootechnical improvements of livestock breeds promoted by the Moroccan post-colonial state, a new sheep breed, the Sardi, was introduced. Compared to the local variety (the Beldi), the Sardi spend more time in pens, consume more grain, but are more productive if well fed (they can be almost double the size). Due to a rise in income since the 1960s (mainly linked to migratory work in the mines of France and Morocco), a new local elite evolved. Members of this elite, with the wealthier agro-herders already existing before the migration process, were able to invest in a Sardi/Beldi hybrid. During the 1980s, they were followed by the less wealthy agro-herders who preferred to remain rather than migrate to Europe. They strove to accumulate capital to invest, mainly from local agro-pastoral benefices and migrations within Morocco connected with agriculture and construction that flourished as the Moroccan economy expanded. Presently, all the sheep in Warzazt are cross-bred with the Sardi. The adoption of the new variety changed the composition of the herds of many of the Atlasic populations. Thanks to new animal alimentation approaches (augmentation of cereal production, mechanization of harvest, use of new fertilizers, etc.), the ratio of sheep to other domestic animals (goats, cows and mules) has increased between 1980 and the present (Dominguez 2010). Hereafter we refer to the Sardi/Beldi hybrid as "Sardi" or simply "sheep".
A second important change in the use of the Yagour was the expansion of cereal growing, which has allowed the cultivation of barley and wheat as complementary food for the now abundant Sardi (Demay 2004). Almost everyone profited either through direct cultivation or through working as wage laborers on the lands of other bigger owners. Our ethnographic understanding of the population, and the results of our interviews with various informants, suggest that the amount of cultivated area at least doubled between 1980 and 2006 (Fig. 2). The jmaa never took a formal stand against this transition, but many locals see this process as a violation of the old Agdal regulations, which designated the territory as pasture.

These two changes in the traditional uses of the Yagour have most likely had a negative impact on natural resources, as has happened in other Agdal-managed sites (Hammi et al. 2007; Auclair and Alifriqui 2010; Dominguez and Hammi 2010). A study in the Yagour addressing the consequences of agricultural development and increasing human presence found that higher rates of biodiversity occur in the areas managed by the traditional Agdal system compared with

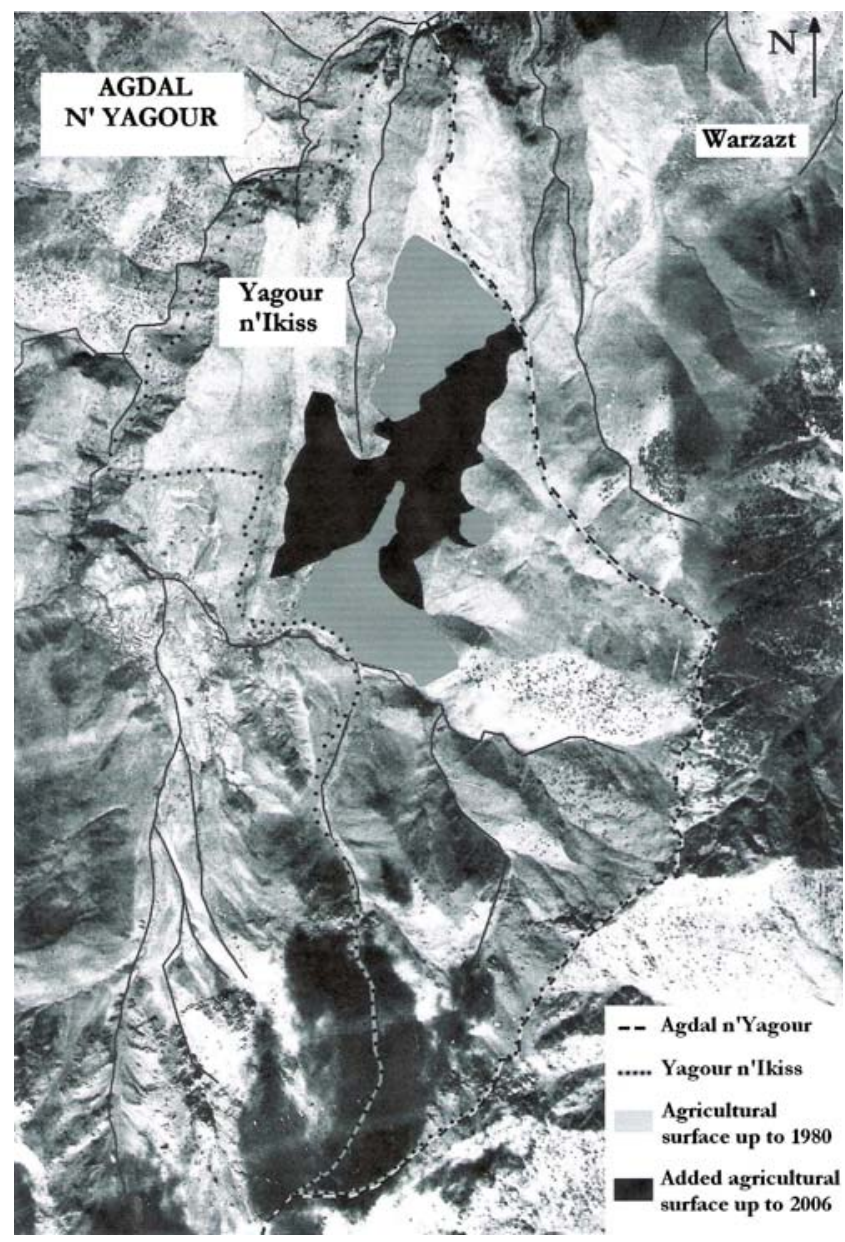

Fig. 2 Situation of cultivated surface in the Yagour n'Ikiss in 1980 and 2006 
Agdals serving new functions such as the area under study, Yagour n'Ikiss (Dominguez and Hammi 2010). The introduction of a monoculture of wheat or barley to feed the Sardi accelerated the loss of natural biological diversity in the area (principally plants and local entomo-fauna). For example, agriculture on the Yagour n'Ikiss now occupies $80 \%$ of its densest pastures (Demay 2004). Also the disappearance of the pastures often results in social conflicts because the herders of Warzazt take their animals beyond their traditional boundaries searching for better pastures, impinging on their neighbors, who are less and less tolerant.

\section{Hypothesis}

We hypothesize that the arrival of the two phenomena examined here (agricultural expansion and the advent of the cross-bred Sardi), is associated with the diminution of the belief in the Saints. Specifically, we expect to find that weaker attachment to traditional beliefs in the Saints would have (a) a positive association with the number of Sardi sheep and (b) a positive association with the increase in the area under cultivation in the Yagour. The hypothesis emerges from the observation that the decline in the traditional belief in Saints coincided with the arrival of the Sardi, and the growth of area under cultivation in the Yagour. Indeed, cultivating more land and owning more Sardi sheep does not seem compatible with traditional beliefs in Saints, since the new strategy is more individualistic, generates shorter term benefits, and opposes the Saints' old philosophy that promotes communal management and long term benefits. Nevertheless we do not assert causality, simply that these two phenomena are associated.

\section{Methods}

Since not everyone's beliefs in Saints have changed in the same way, and not everyone has adopted, to the same extent, the more productive-individualistic economic model of Sardi sheep and agriculture extension, we can examine the association between the first and the latter. This research is based on participant observation (between 2003 and 2008) and a formal survey (June-September 2007).

\section{Participant Observation}

Participant observation was spread over a total of 12 months, between 2003 and 2008 and through all agro-pastoral seasons. Living in the homes of the community permitted us to obtain a good understanding of religious representations and beliefs, their association to the Agdal rules and to the Yagour territory, and their different ecological behaviors. This includes things such as how people deal with new ways of land appropriation, reformulation of Agdal rules, privatization of communal territories, and transformation of traditional beliefs in Saints. Participant observation has been the strongest base on which to found our subsequent survey and the interpretation of quantitative findings.

\section{Survey}

Sample We interviewed male heads of households in Warzazt (97 households) during our 2007 survey. If heads were absent, we interviewed the eldest male of the household present. We have complete data for 80 of the 97 male heads of households in Warzazt. Of the remaining, we have incomplete data for three male heads of households and no data for 14 informants because there was no adult male present during the survey period.

Men in our sample ranged from 16 to 90 years of age but were generally over 30 (93\%). We excluded women from the survey because men are ostensibly responsible for decisions regarding management practices.

Survey instrument The survey was structured in three sections:

In the first we included questions regarding the household use of the Yagour (e.g., agro-pastoral uses and production of the territory, cultivated area on the Yagour, and number of sheep owned).

The second section included questions on socioeconomic characteristics of the informants, such as general agricultural and animal production, ownership of manufactured goods, income from migration, and nights spent out of the valley. The questions referred to the period between June 2006 and June 2007.

The last section consisted of a set of questions related to the attachment to traditional beliefs in Saints. Those questions were used to build an index of attachment to beliefs in Saints, hereafter Saints Belief Index (SBI). On average the survey lasted $1 \mathrm{~h}$.

Outcome Variables We used two outcome variables that proxy for natural resources management. The two variables are the number of mature Sardi sheep reportedly owned by the household, and the area under cultivation.

Explanatory variable Our main explanatory variable was the belief of the informants in the local Saints, measured through an index created on the basis of eight questions concerning the informants' faith in the Saints religious tradition. To construct the eight questions we first used ethnographic information collected during the previous 3 years of fieldwork, informal discussions, and formal focus groups, where we conceptualized the operant system. Through these combined methodol- 
ogies we explored, among others, local religious beliefs and sayings about the Saints, and socio-economic attributes (see Table 2). For each of the eight questions we asked informants to indicate their level of attachment on a scale from 1 to 5 , where 1 represented the lowest and 5 the highest attachment to the beliefs in Saints.

Control variables We also collected information about attributes that may affect our outcome and explanatory variables, such as 'age of informant' and 'Household Market integration,' which is based on three preconstructed variables: 1.) 'Ownership of Manufactured Goods', which records the addition of the monetary cost of things owned by the household and obtained outside the valley such as solar panels, batteries, televisions and toilets; 2.) 'Income including currency received by the household from outside remittances;' and 3.) 'Income from activities in the community,' which records the annual monetary value obtained by the household through local agro-pastoral production. This was obtained by giving the monetary price found at the local market to each type of gross production of the families, excluding gross income from emigration (following Dominguez et al. 2010). To combine the information on these three previous variables and to obtain the final single variable that we called 'Market Integration,' we ran a Principal Component Analysis (PCA). Although income is defined as a flow, material goods and ownership of assets is a stock, hence their grouping together might be criticized. Therefore, we decided to combine them into a single variable because they were significantly correlated. It would be useful to incorporate additional control factors in the statistical models, however, our small sample limits the number of control variables that we can include in the model.

\section{Data Analysis}

We performed a factor analysis for the eight questions relating to the SBI to detect the relation between the eight questions. Factor analysis allowed evaluation of whether all questions measured a single construct and hence whether they could be integrated in an index.

To test our hypotheses, we ran a series of generalized linear models (GLM) to compare the Saints Belief Score (SBS), the number of sheep, and the area under cultivation by each individual. We also included a variable of the square of the SBS to evaluate a potential non-linear association. When using the number of sheep as an outcome variable, we also included as an explanatory variable the area under cultivation, and vice versa. We included age and market integration as controls in all our models. We specified Poisson distributions with log link functions for the outcome variables, and we also scaled the standard errors using the square root of the Pearson chisquare dispersion and, adjusted them to compensate for the over-dispersion in the Poisson distribution.

We then ran a set of different regression models for each outcome variable. First, we ran a model with the outcome variable against the religious index and controls. Then we ran a set of complementary models intentionally dropping one or more control variables. Finally we ran a model using information from those households that had at least one sheep (sheep $>0$ ). All these models allowed us to evaluate the robustness of our findings. In order to evaluate the accuracy of our models, after each model we ran a Pearson correlation between predicted and observed values.

\section{Potential Biases}

The survey was conducted by a local Berber, who had long experience in the community and who has collaborated with the lead author since 2003 . He is from a village $8 \mathrm{~km}$ from Warzazt and also a member of the Mesiouia tribe, but is not included in the studied population. He has finished High School and is member of a local NGO (Association des Amis du Zat) acting in various locations in the valley, Warzazt included. The personal relationship between the enumerator and the informants may decrease biases arising from personal mistrust among local people towards a known pollster (i.e., a desire to hide their real economic status, to avoid local curiosity about their private property, or fear of being socially undervalued). Nevertheless, it has undoubtedly opened many more doors than it has closed, since we observed over time that his relationship with the local population was always excellent.

Other potential biases in the estimations consist of i) random measurement error, ii) omitted variable bias, and iii) reverse causality. First, random measurement error may arise from inaccurate estimations of the variables that capture the number of sheep and the area under cultivation, because people generally give a rounded off inventory when answering. It is also possible that some people may not have understood some of the questions used to construct the Saints Belief Score, or gave responses at random. Random measurement error in the explanatory variable would produce an attenuation bias and make the estimates more conservative.

Second, estimations may be biased by the role of omitted variables. We have tried to attenuate these biases through the use of control variables in our robustness test. Nevertheless, the number of informants in our sample is relatively small and does not allow us to simultaneously include many control variables in the model. Finally, we do not have instrumental variables sufficient to allow us to speak about causality, only about associations among the explored variables. 
Table 1 Definition and summary statistics of variables used in the main analysis among Mesioui's households $(N=80)$ of Warzazt, Morocco, 2007

\begin{tabular}{|c|c|c|c|}
\hline Variable & Definition & Mean (std. dev) & Min-Max \\
\hline Saint's beliefs index & $\begin{array}{l}\text { Sum of responses to eight questions on level of attachment } \\
\text { to the saints' tradition. From } 8 \text { (lowest attachment) to } 40 \\
\text { (highest attachment). }\end{array}$ & $22.54(12.84)$ & $8-40$ \\
\hline Square of saint's beliefs index & Square of the Religiousness score & $670.7(618.5)$ & $64-1600$ \\
\hline $\begin{array}{l}\text { Number of cross-breaded Sardi } \\
\text { sheep }\end{array}$ & Number of cross-breaded Sardi sheep owned by the household. & $16.0(26.8)$ & $0-150$ \\
\hline Cultivated surface in the Yagour & $\begin{array}{l}\text { Surface of cultivated land in the Yagour by household. In abraas, } \\
\text { ( } 6 \text { abraas } \approx 1 \text { hectare })\end{array}$ & $11.82(8.8)$ & $0-40$ \\
\hline Age & Informant's Age, in years & $50.41(16.6)$ & $17-94$ \\
\hline \multirow[t]{5}{*}{ Market integration } & $\begin{array}{l}\text { Variables (mean; Std.Dev.) used to construct the Market integration } \\
\text { (all variables in Dirham: }=10 \text { USD, 2007) } \\
\text { Income from emigration (mean }=10.7 \text { thousand; } S D=9.4 \text { thousand) }\end{array}$ & \multirow[t]{5}{*}{$0.013(1.8)$} & \multirow[t]{5}{*}{$-1.65-6.07$} \\
\hline & $\begin{array}{l}\text { Income from outside activities (mean }=24.9 \text { thousand; } \\
\mathrm{SD}=26.6 \text { thousand) } \\
\text { Solar Panels (mean }=812.5 ; \mathrm{SD}=411.7 \text { ) }\end{array}$ & & \\
\hline & Televisions: $($ mean $=105 ; \mathrm{SD}=143.9)$ & & \\
\hline & Batteries $($ mean $=72.5 ; \mathrm{SD}=96.8)$ & & \\
\hline & Toilets $($ mean $=11.3 ; \mathrm{SD}=57.4)$ & & \\
\hline
\end{tabular}

\section{Results}

In Table 1, we present definition and summary statistics of the outcome, explanatory, and control variables used in the regression analyses.

\section{Beliefs in Saints}

Scores higher than three on questions on Saints Beliefs indicated closeness to traditional Saints Beliefs, whereas scores lower than three indicated distance from traditional Saints beliefs. The descriptive statistic of the questions on Saints Beliefs (Table 2) indicated that only one question, (a) the importance of ritual celebrations near the tomb of the village's Saint to collectively celebrate the migration to the highlands, had a mean significantly higher than 3 (mean= $3.74, \mathrm{SD}=1.84$ ). Four questions had a mean value close to the midpoint of 3 (between 2.89 and 3.03). Those included (b) the belief in the old opening date of the pastures (mean= $2.89, \mathrm{SD}=1.91$ ), (c) the belief in the importance of offerings to obtain blessing (mean $=2.78, \mathrm{SD}=1.83$ ), (d) the belief that animals will become ill if they enter the Agdal-managed area during the prohibition period (mean $=2.93, \mathrm{SD}=1.89$ ), and (e) the belief in the healing potential of the $3700 \mathrm{~m}$ Meltsene mountain peak (mean=3.03, $\mathrm{SD}=1.95$ ). The mean value of the remaining three questions was significantly lower than 3 (between 2.518 and 2.222), suggesting that, overall, our sample did not hold those traditional beliefs. Those were (f) the belief in the capacity of the Saint's descendants to manage the Agdal (mean=2.50, SD=1.88), (g) the importance of celebrating rituals near the tomb of the Saint Sidi
Boujmaa every August (mean $=2.24, \mathrm{SD}=1.79)$ and $(\mathrm{h})$ the tradition of shaving the children's heads at Sidi Boujmaa's village (mean=2.44, $\mathrm{SD}=1.89$ ). The standard deviation of responses to all the questions was high, suggesting large variation among informants. ${ }^{1}$

Saints Beliefs, Sheep Ownership, and Cultivated Area in the Yagour

Table 3 contains the results of the GLM. There were four noteworthy findings. First, the SBS was positively and significantly correlated with the number of sheep owned by a household (Columns [a], row [1] of Table 3). The square of the SBS was associated in a negative and statistically significant way with number of sheep owned by a household (Columns [a], row [2] of Table 3). Taken together, the two coefficients suggested that the association between the number of sheep owned by a household and

\footnotetext{
${ }^{1}$ The results from factor analysis for the answers of the eight questions of SBI suggested that questions about the beliefs converged on one factor (ratio between two first Eigenvalues=25.74). Reliability analysis using Chronbach alpha confirmed the internal consistency in the scale used to evaluate Saints Beliefs (alpha=0.95). Because responses showed a high internal consistency, we used the responses to the eight questions to construct an individual score of attachment to traditional SBI. Specifically, we generated an overall individual score by adding the scores obtained on the eight questions. The average SBS was $22.54(\mathrm{SD}=12.84)$, where the maximum score was 40 , the minimum 8 and the mathematical midpoint 24 . The average score in the overall sample was slightly under the midpoint and the analysis of the answers described a population spread very equally among the whole spectrum between the two extremes (modernity and tradition).
} 
Table 2 Descriptive statistic of the values given by respondents $(N=80)$ to questions about Saint's Beliefs among Mesioua tribe

\begin{tabular}{|c|c|c|c|}
\hline & Situation related with the saint's Beliefs & Mean & Std Dev \\
\hline I & $\begin{array}{l}\text { Where would you situate yourself in a scale from } 1 \text { to } 5 \text { concerning the importance to vote for the traditional } \\
\text { opening date of the agdal? } 1=\text { "not important at all"; } 5=\text { "very important". }\end{array}$ & 2.89 & 1.91 \\
\hline II & $\begin{array}{l}\text { Where would you situate yourself in a scale from } 1 \text { to } 5 \text { concerning the importance of the traditional role of } \\
\text { the saints in the agdal management? } 1=\text { "not important at all"; } 5=\text { "very important". }\end{array}$ & 2.50 & 1.88 \\
\hline III & $\begin{array}{l}\text { Where would you situate yourself in a scale from } 1 \text { to } 5 \text { concerning the importance of the traditional belief } \\
\text { on making rituals in order to maintain the agdal system? } 1=\text { "not important at all"; } 5=\text { "very important". }\end{array}$ & 2.78 & 1.83 \\
\hline IV & $\begin{array}{l}\text { Where would you situate yourself in a scale from } 1 \text { to } 5 \text { concerning the importance of the traditional belief } \\
\text { saying that if animals enter the Yagour before the opening date, they will become ill? } 1=\text { "not important } \\
\text { at all"; } 5=\text { "very important". }\end{array}$ & 2.93 & 1.89 \\
\hline $\mathrm{V}$ & $\begin{array}{l}\text { Where would you situate yourself in a scale from } 1 \text { to } 5 \text { concerning the importance about making traditional } \\
\text { maaroufs (animal sacrifice and collective meal) near the tomb of the saint of your village to celebrate together } \\
\text { ascendance to the highlands in order to receive the blessing of Allah (God)? 1="not important at all"; } \\
5=\text { "very important". }\end{array}$ & 3.73 & 1.84 \\
\hline VI & $\begin{array}{l}\text { Where would you situate yourself in a scale from } 1 \text { to } 5 \text { concerning the importance about making traditional } \\
\text { maaroufs every august in the village of the big saint of the Yagour Sidi Boujmaa? 1="not important at all"; } \\
5=\text { "very important". }\end{array}$ & 2.24 & 1.79 \\
\hline VII & $\begin{array}{l}\text { Where would you situate yourself in a scale from } 1 \text { to } 5 \text { concerning the importance of the traditional belief } \\
\text { saying that if they go up to the the Meltsene pick with sick animals, many will be cured? } 1=\text { "not important at } \\
\text { all"; } 5 \text { ="very important". }\end{array}$ & 3.03 & 1.95 \\
\hline VIII & $\begin{array}{l}\text { Where would you situate yourself in a scale from } 1 \text { to } 5 \text { concerning the importance about the traditional } \\
\text { shaving of the heads of the children at their early stages of life? } 1=\text { "not important at all"; } 5=\text { "very important". }\end{array}$ & 2.44 & 1.89 \\
\hline
\end{tabular}

the attachment to Saints Beliefs of the household head resembles an inverted-U. Considering all models run, we calculated an inflection point in the association between the number of sheep owned by a household and the attachment to Saints Beliefs of the head of household. The inflection point ranges from 17.33 to 31.13 , with an average across models of 25.88 points ( 24 being the midpoint of the SBS). This finding meant that an increase in the SBS anywhere from 8 (minimum on the Saint's Beliefs scale) to 25.88 (average inflection point) was associated with an increase in the number of sheep owned by the household, but after the inflection point an increment on the SBS is associated to a decrease in the number of sheep. We analyze this relationship further in the next section. A Pearson correlation suggested that predicted values from models fitted well with the observed values among the informants. For instance, the model presented in Table 3 (Column [a]-row [7]) had a significant correlation between predicted and observed values of R2=0.93 $(p<0.001)$.

Second, the results of the regressions using cultivated area as the outcome variable also suggested a non-linear association between household cultivated area in the Yagour and the SBS, are possibly suggestive but inconclusive (Columns [b], row [1]-[2] of Table 3).

Table 3 Associations between number of sheep, cultivated surface in the Yagour and Saint's Beliefs Index among Mesioui's households in Warzazt, Morocco, 2007

\begin{tabular}{|c|c|c|c|}
\hline \multirow[t]{2}{*}{ Explanatory variables } & & \multicolumn{2}{|l|}{ Outcome Variables } \\
\hline & & $\begin{array}{l}\text { Number of sheep } \\
{[\mathrm{a}]}\end{array}$ & $\begin{array}{l}\text { Cultivated surface in the Yagour } \\
\text { [b] }\end{array}$ \\
\hline Saint's belief index & {$[1]$} & $0.085^{\mathrm{a}}(0.044)$ & $0.052(0.042)$ \\
\hline Saint's belief index square & {$[2]$} & $-0.002^{\mathrm{b}}(0.000)$ & $-0.001(0.001)$ \\
\hline \multicolumn{4}{|l|}{ Control variables } \\
\hline Cultivated surface in the Yagour & {$[3]$} & $0.021^{\mathrm{a}}(0.011)$ & $\wedge$ \\
\hline Number of sheep & {$[4]$} & $\wedge$ & $-0.001(0.004)$ \\
\hline Market integration & {$[5]$} & $0.508^{\mathrm{c}}(0.047)$ & $0.153 * *(0.071)$ \\
\hline Age & {$[6]$} & $0.0160^{\mathrm{b}}(0.006)$ & $-0.0001(0.005)$ \\
\hline Pearson's Correlation (predicted vs Observed Values) & [7] & $0.93^{\mathrm{c}}$ & $0.81^{\mathrm{c}}$ \\
\hline
\end{tabular}

Generalized Linear Models with Poisson distribution, log link function and adjustment of standard error for over-dispersion. Cells contain coefficient estimates and, in parenthesis, standard errors. ${ }^{\mathrm{a}},{ }^{\mathrm{b}}$ and ${ }^{\mathrm{c}}$ significant at $10 \%, 5 \%$, and $1 \%$ level. ${ }^{\wedge}=$ variables intentionally excluded. Models contain a constant not showed. For definition of variables see the Table 1. 
The third noteworthy finding was that the size of the cultivated area did not have a strong association with the Saints Beliefs. When we used the number of sheep as an outcome variable we found a positive and statistically significant association between number of sheep and the SBS (Columns [a], row [3] of Table 3), but when we used cultivated area as an outcome variable the association was negative and statistically insignificant (Columns [b], row [4] of Table 3). Robustness analyses also suggested that relationship between sheep and cultivated area was weak.

The fourth and last noteworthy finding comes from the results of the robustness analyses. Robustness analyses suggested that the sign, coefficient, and significance level of the association between the number of sheep and Saint's SBI did not change across models. Some slight changes in coefficients between number of sheep and SBI were observed when we dropped from the models either the square of the index or the variable that proxies for integration into the market. Robustness analyses also indicated that the correlations between predicted and observed were lower $(\mathrm{R} 2<0.50)$, when we did not control for integration into the market, than when we did so, whereas cultivated area was not statistically associated to the SBI in most of the models. Cultivated area was statistically associated to number of sheep only in four of the nine models.

\section{Parabolic Relationship Between SBS and Household Sheep Ownership}

To explore the inverted-U shape relationship between the SBS of a head of household and the number of sheep owned by that household, we constructed a dichotomous variable based on the SBS. We used the mean inflection point (25.88) as the cut off point and assigned the value of 1 to the new dichotomous variable if the respondent scored more than 25.88 on the SBI ( $n=34,42.5 \%$, hereafter strong believers) and 0 otherwise ( $n=46,57.5 \%$, hereafter weak believers). We then ran a set of Probit regressions with the dichotomous variable as the outcome variable. We set the model to obtain the change in the probability for an infinitesimal change in each explicatory variable, instead of coefficients. For explanatory variables, we chose those that may have affected both the individual Saints Beliefs and the household's ability to engage in sheep rearing. Such variables included 'Income from Emigration', 'Income from Activities in the Community' (both variables explained above), and 'Number of Nights Spent Outside the Valley'. The variable 'Number of Nights Spent Outside the Valley' captures the quantity of days people spent outside the community (e.g. Marrakech or other big cities, agricultural fields all over Morocco, foreign countries, etc.) in the year before the survey. We also used the age of informants as a control variable. Due to our small sample size we could not use many explanatory variables in the analysis, so we ran a set of regression models using different triads of explanatory variables. Regression results suggest that weak believers (SBS $<=25.88$ ) spent more nights outside the community than strong believers (SBS $>=25.88$ ) (columns [a]-[d], row [1] of Table 4). For instance, in row [1], column [a] of Table 4 , one additional night outside the valley during the year - over the average of the sample - was associated with a $0.3 \%$ lower probability of being in the group of strong believers $(p=0.01)$. Results also suggested that strong believers obtained more remittances from emigration (generally from third persons like a son or a brother outside the community) than weak believers (Columns [a]-[c], row [2] of Table 4). However, though the association between strong believers and income from emigration was statistically significant, the magnitude of the association was low. Last, income from activities inside the community is not associated with the believer groups. Results among all the regression models presented in Table 4 (columns [a] to [c]) were consistent.

\section{Discussion}

The discussion will be basically focused on the quantitative results from our analysis and not on general issues, which we will analyze in the Conclusion. Our main finding suggested that there was an association between the abandonment of traditional beliefs in the Saints and Sardi sheep ownership. Within this association we have identified an inverted-U curve from which we differentiated between two groups. First, among the people with an SBS lower than 25.88 (weak believers), the lower the informant's SBS, the lower the number of sheep. Second, among the people with an SBS higher than 25.88 (strong believers), the lower the informant's SBS, the higher number of sheep.

For the group of weak believers, we found that the greater the belief, the higher the number of sheep owned by the household, thus contradicting our initial hypothesis. We explain that finding with results in Table 4: people who had discarded their beliefs spent more nights outside the valley. A plausible explanation for our contra-intuitive finding is that people who spent time out of the valley would maintain a lower attachment to beliefs since they are more exposed to external cultural factors. At the same time, these people could rear fewer animals because they simply had less time in the valley than the strong believers. In any case, we agree that this is an incomplete explanation and that further research must be undertaken.

Concerning the strong believers, we found that the lower the belief, the higher the number of sheep owned by the household, thus confirming our initial hypothesis. This could 
Table 4 dprobit regressions between "believer groups" and socioeconomic attributes of individuals of Warzazt, Morocco, 2007. Believer people= 1 if Saint's Beliefs index score $<25.88$, and Less believer people $=0$ otherwise

\begin{tabular}{llllll}
\hline Explanatory variables & & {$[\mathrm{a}]$} & {$[\mathrm{b}]$} & {$[\mathrm{c}]$} & {$[\mathrm{d}]$} \\
\hline Nights outside the valley & {$[1]$} & $-0.003^{\mathrm{b}}(0.001)$ & $-0.003^{\mathrm{b}}(0.001)$ & $\wedge$ & $-0.004^{\mathrm{b}}(0.001)$ \\
Income from emigration & {$[2]$} & $1.2 \times 10^{-5 \mathrm{a}}\left(6.3 \times 10^{-6}\right)$ & $\wedge$ & $8.44 \times 10^{-6}\left(7.16 \times 10^{-6}\right)$ & $1.94 \times 10^{-5}\left(7.63 \times 10^{-6}\right)$ \\
$\begin{array}{l}\text { Income from activities } \\
\text { inside of community }\end{array}$ & {$[3]$} & $\wedge$ & $-7.34 \times 10^{-7}\left(2.07 \times 10^{-6}\right)$ & $-1.63 \times 10^{-6}\left(2.41 \times 10^{-6}\right)$ & $-2.93 \times 10^{-6}\left(2.49 \times 10^{-6}\right)$ \\
Age & {$[4]$} & $0.008^{\mathrm{b}}(0.004)$ & $0.01^{\mathrm{b}}(0.004)$ & $0.01^{\mathrm{b}}(0.004)$ & $\wedge$ \\
Pseudo-R & {$[6]$} & 0.24 & 0.21 & 0.13 & 0.21 \\
\hline
\end{tabular}

Sample size $=80$. cells contain marginal effects based in maximum Likelihood coefficient estimates and, in parenthesis, standard errors. ${ }^{\mathrm{a}},{ }^{\mathrm{b}}$ and ${ }^{\mathrm{c}}$ significant at $10 \%, 5 \%$, and $1 \%$ level. $\wedge=$ variables intentionally dropped. Due to relatively small sample size of outcome variable, we ran a set of probit regressions using a different trio of explicatory variables. Each column corresponds to a regression model.

be explained by the changes in socio-economic and beliefs systems noted before. Men who went to work in France in the 1960s and 70s, or for seasonal work within Morocco mainly after 1980, upon return to Warzazt invested their capital in land and sheep. Because of their experience in the outside world, their coincident abandonment of beliefs was especially strong. Ideas that arrived with returnees could have contributed to local reinforcement of the ideology of short term individual profit, symbolized by Sardi sheep, to the detriment of established practices.

Our results also indicated that the increase in cereal cultivation, was not significantly associated with attachment to individual beliefs. Regarding the amount of cultivated area, our results suggested that it is weakly associated with sheep ownership. Some models suggest a positive and statistically significant association between cultivated area in the Yagour and number of sheep, whereas in others the association was absent. The weak association that we statistically found between the cultivated area and the number of sheep, can nevertheless be supported by our field observations and quantitative findings from other research prior to ours (Demay 2004). This statistical finding should be considered with caution as it may be an effect of the small size of our sample of only 54 informants having sheep. In any case, we cannot assure that there is no association, only that we could not demonstrate statistically the potential association between cultivated area and number of sheep. Despite this, changes in traditional beliefs could still be indirectly linked to the extension of cultivated area on the Yagour through sheep ownership.

\section{Conclusions}

This study has found an association between individual beliefs in Saints and a use of High Mountain pastures in central Morocco. Our findings dovetail with previous qualitative researches in other parts of the world that suggest that religious beliefs are associated with natural resource management (Luo Yafeng et al. 2009; Byers et al. 2001; Wadley and Colfer 2004). They also add religious beliefs to the list of factors that change as natural resource utilization changes for whatever reason, be it climate change, population increase, migration, technical advances or expansion of market economies. Of course, as we point out in our Introduction, the presence of these more measurable dimensions decidedly affects the different uses of communal lands and their management institutions worldwide, and the Yagour is no exception. These change-factors undoubtedly have a fundamental role in modifying agro-pastoral processes all around the globe (Turner and Brush 1987). More particularly, other mountain districts of Morocco are undergoing almost identical processes (Bourbouze 1999; Auclair and Alifriqui 2010). For example, Moroccan mountain farmers insist that a generalized trend towards warmer years in recent decades has favored the introduction of non-intensive cereal cultivation at altitudes above $2000 \mathrm{~m}$. This hardly existed before the 1980s and now facilitates the introduction of Sardi sheep, which have spread to almost all corners of the High Atlas, and which need grain for their existence and development. Moroccan mountain population levels have very significantly increased since the 1960s and that this, in turn, engenders similar agro-economic changes. Technological advances have also transformed traditional uses of high pasture regions. For example, since the turn of the millennium, the incidence of small threshing machines, imported from Turkey, has considerably increased. These are capable of doing in $1 \mathrm{~h}$ the work that one man could do in 2 weeks. What this study has tried to highlight, is that individual religious beliefs, or lack of them, can also be an important element in the use of agro-pastoral resources. Our study suggests that researchers should pay greater attention to individual beliefs and belief systems. While the strength and importance of people's beliefs should not be overstated or idealized, it seems that they cannot be ignored either. 
Acknowledgements Research was funded by a Marie Curie Grant (MIRG-CT-2006-036532) and Programme AGDAL (biodiversité et gestion communautaire de l'accés aux ressources sylvopastorales È / I. F.B-I.R.D financement $n_{i}$ 2886). Zorondo-Rodriguez is funded by a 'Presidente de la Repœblica' scholarship from the Chilean State, and Dominguez by the 'Formation à la recherche' scholarship from the University Agency of the Francophonie, the 'Field work' scholarship from the UNESCO Fellowship Program and the ÒBECAS MAEAECIDÓ from the Spanish Agency of International Cooperation and Development.

We thank Mjid Mourad for his excellent work as translator and enumerator, all the members of the local Association des amis du Zat, and especially its president Ahmed Bellaoui, for having granted us so many facilities for approaching the local communities. We especially thank too the members of the team USAGES of the Laboratoire Population-Environnement-Développement of Marseille that gave constant trust and intellectual and material support to Pablo Dominguez for the researches previous to this, which indirectly permited the achievement of the present text. We especially think in Laurent Auclair, Didier Genin and Bruno Romagny. We also want to thank Ricardo Godoy, Jose Luis Molina, Erik Gomez, Kathryn Demps and Pablo Manzano, for their kindness in reading this text and suggesting numerous improvements, and all our very patient and cooperative field informants. The comments of the anonymous reviewers of Human Ecology were also very useful in preparing the final version of our work.

\section{References}

Alaoui-Haroni, S. (2009). Les pelouses humides dans le haut Atlas : Biodiversité végétale, dynamique spatiale et pratiques de gestion coutumičre. Ph.D Thesis, University of Cadi Ayyad, Laboratoire d'Ecologie végétale. Marrakech, Morocco.

Auclair, L., and Alifriqui, M. (2010). Agdals. Société et gestion des ressources dans l'Atlas marocain. Actes du colloque. Les Agdals de l'Atlas marocain. Savoirs locaux, droits d'accès, gestion de la biodiversité È. Institut Royal de la Culture Amazighe-Institut de Recherche pour le Développement, Rabat

Baland, J.-M., and Platteau, J.-P. (1999). The Ambiguous Impact of Inequality on Local Resource Management. World Development 27(5): 773-788.

Bellaoui, A. (1989). Les pays de l'Adrar-n-Dern. Etude géographique du Haut Atlas de Marrakech. Ph.D dissertation, Université de Tours, Département de Géographie, France.

Bourbouze, A. (1999). Gestion de la mobilité et résistance des organisations pastorales des éleveurs du Haut Atlas marocain face aux transformations du contexte pastoral maghrébin. In M. Niamir Fuller (ed.), Managing mobility in african rangeland: the legitimization of transhumance, London, IT publications: FAO and Beijer intern. instit. Ecolog. Economics.

Bourbouze, A., and Quarro, M. (2000). Rupture: nouveaux enjeux, nouvelles fonctions, nouvelle image de l'élevage sur parcours. Options Méditerranéennes 39: 246.

Byers, B. A., Cunliffe, R. N., and Hudak, A. T. (2001). Linking the Conservation of Culture and Nature: A Case Study of Sacred Forests in Zimbabwe. Human Ecology 29: 187-218.

Cinner, J., Marnane, M. J., McClanahan, T. R., and Almany, G. R. (2006). Periodic Closures as Adaptive Coral Reef Management in the Indo-Pacific. Ecology and Society 11 (1): 31. [online] URL:http://www.ecologyandsociety.org/vol11/iss1/art31/

Demay, S. (2004). Diagnostic agraire dans le Haut Atlas marocain. Territoire des Ait Ikiss. Master dissertation, INA Paris-Grignon, France.

Dianteill, E. (2002). Pierre Bourdieu et la religion synthese critique d'une synthese critique. Arch. de Sc. soc. des Rel. 118: 5-19.
Dominguez, P., and Hammi, S. (2010). L'Agdal du Yagour, Écologie et pastoralisme. Ecologia y Pastoralismo, Ed. Koldo Michelena, Donostia.

Dominguez, P., Bourbouze, A., Demay, S., Genin, D. and Kosoy, N. (2010). Culturally Mediated Provision of Ecosystem Services: The Agdal of Yagour. Environmental Values.

Dominguez, P. (2010). Représentations et utilisations culturelles de l'environnement chez les agro-pasteurs berbéres du Haut Atlas marocain: le cas des Agdal dans le haut plateau de Yagour. Ph.D dissertation, École des Hautes Études en Sciences Sociales, Laboratoire d'Anthropologie Sociale, Paris, France / Universitat Autonoma de Barcelona, Départament d'Antropologia Social i Cultural, Bellaterra, Spain.

Elmqvist, T., Berkes, F., Folke, C., Angelstam, P., Crepin, A. S., and Niemela, J. (2004). The Dynamics of Ecosystems, Biodiversity Management and Social Institutions at High Northern Latitudes. Ambio 33: 350-355.

Evans-Pritchard, E. (1970). African Political Systems International. Oxford University Press, London.

Fillat, F. (2003). Gestion semiextensiva de prados y pastos europeos ricos en especies. Caso particular de los pirineos españoles. Pastos 33(2): 171-215.

Folke, C., Pritchard, L., Berkes, F., Colding, J., and Svedin, U. (2007). The Problem of Fit Between Ecosystems and Institutions: Ten Years Later. Ecology and Society 12(1): 30. [online] URL: http:// www.ecologyandsociety.org/vol12/iss1/art30/

Garcia, C., Pascal, J. P., and Kushalappa, Ch G (2006). Les forêts sacrées du Kodagu en Inde: Écologie et religion. Bois et forêts des tropiques 288(2): 5-13.

Gellner, E. (1969). Saints of the Atlas. Weidenfield and Nicholson, London.

Godoy, R., Reyes-Garcia, V., Byron, E., Leonard, W., and Vadez, V. (2005). The Effect of Market Economies on the Well-Being of Indigenous Peoples and on Their Use of Renewable Natural Resources. Annual Review of Anthropology 34: 121-138.

Hammi, S., Al Ifriqui, M., Simonneaux, V., and Auclair, L. (2007). Évolution des recouvrements forestiers et de l'occupation des sols entre 1964 et 2002 dans la haute vallée des Ait Bouguemez (Haut Atlas Central, Maroc). Sécheresse 18(4): 271-277.

Hardin, G. (1968). The Tragedy of the Commons. Science 162: $1243-$ 1248 .

Herzenni, A. (1993). Gestion des ressources et conditions de développement local dans la haute montagne de la province d'Azilal (Maroc). In A. Bencherifa (ed.), Montagnes et hauts pays de l'Afrique : utilisation et conservation des ressources, Marrakech, Pub. De la Faculté des Lettres et Sciences Humaines, ser. Colloques et Sém.

Kingsbury, N. D. (2001). Impacts of Land Use and Cultural Change in a Fragile Environment: Indigenous Acculturation and Deforestation in Kavanayen, Gran Sabana, Venezuela. Interciencia 26(8): $327-336$

Lansing, J. S. (1987). Balinese "Water Temples" and the Management of Irrigation, American Anthropologist. New Series 89(2): 326-341.

Lu, F. (2007). Integration into the Market Among Indigenous Peoples: A Cross - Cultural Perspective from the Ecuadorian Amazon. Current Anthropology 48(4): 593-602.

Netting, R. M. (1986). Cultural Ecology. Weveland, Long Grove.

Neves-Garca, K. (2004). Revisiting the Tragedy of the Commons: Ecological Dilemmas of Whale Watching in the Azores. Human Organization 63: 289-300.

Ostrom, E. (1990). Governing the Commons. The Evolution of Institutions for Collective Action. Cambridge University Press, Cambridge.

Parlee, B., and Berkes, F. (2006). Indigenous Knowledge of Ecological Variability and Commons Management: A Case Study on Berry Harvesting from Northern Canada. Human Ecology 34(515): 528. 
Romagny, B., El Gueroua, A., and Auclair, L. (2008). La gestion des ressources naturelles dans la vallée des Ait Bouguemez (Haut Atlas): la montagne marocaine à la recherche d'innovations institutionnelles. Mondes en développement 36(141): 63-80.

Thoms, Ch A (2008). Community Control of Resources and the Challenge of Improving Local Livelihoods: A Critical Examination of Community Forestry in Nepal. Geoforum 39: 14521465 .
Turner, B. L., and Brush, S. B. (1987). Comparative Farming Systems. The Guilford, New York.

Wadley, R. L., and Colfer, C. J. P. (2004). Sacred Forest, Hunting, and Conservation in West Kalimantan, Indonesia. Human Ecology 32: $313-338$.

Yafeng, L., Jinlongb, L., and Dahonga, Z. (2009). Role of Traditional Beliefs of Baima Tibetans in Biodiversity Conservation in China. Forest Ecology and Management 257: 1995-2001. 